\title{
Development of Learning Flow on Two-Dimentional Figure Based Realistic Mathematics Education
}

\author{
Jesi Alexander Alim ${ }^{1, *}$, Ahmad Fauzan², I Made Arnawa ${ }^{3}$, Intan Kartika Sari ${ }^{1}$, Neni Hermita ${ }^{1}$ \\ ${ }^{1}$ Faculty of Teacher Training and Education, Universitas Riau, Indonesia \\ ${ }^{2}$ Faculty of Mathematics and Natural Education, Universitas Negeri Padang, Indonesia \\ ${ }^{3}$ Faculty of Mathematics and Natural Education, Universitas Andalas, Indonesia
}

Received May 5, 2020 ; Revised June 15, 2020; Accepted July 7, 2020

Copyright $\subseteq 2020$ by authors, all rights reserved. Authors agree that this article remains permanently open access under the terms of the Creative Commons Attribution License 4.0 International License

\begin{abstract}
Two dimentional figures geometry learning activities that focus on formal procedures, are not able to direct students to develop their reasoning ability in the discovery of the concept itself and its relationship with daily experiences. Because of this, the design of geometry learning in flat shapes uses realistic geometry models that are valid, practical and effective. This research is a design research that combines the Plomp and Gravemeijer \& Cobb development models which consists of three phases: preliminary research (experimental preparation), prototyping phase (conducting experiments, retrospective analysis) and assessment phase. This research produces learning design for flat geometry with realistic geometry models. The learning design that is designed consists of determining the properties of a flat and calculating the area of the flat shape. This research has produced a learning design that meets valid characteristics in terms of content as well as in terms of construction. The result of learning design meets practical characteristics in terms of implementation, ease and time required. The learning design has also fulfilled the effective characteristics in terms of its impact on students 'reasoning abilities where the average test results of students' mathematical reasoning abilities are $76.39 \%$ with a good category. This means, the results of the study show that the design of flat geometrical learning with the realistic geometry model developed has been valid, practical and effective.
\end{abstract}

Keywords Two Dimentional Figures, Realistic Mathematics Education, Hypothetical Learning Trajectory

\section{Introduction}

Geometry as a branch of mathematics has an important role in learning mathematics [5]. Learning geometry enables students to analyze and interpret the world they live in and equip them with tools that they can apply in other fields of mathematics [3, 4, 18, 19].

At first glance geometry concept in learning mathematics looks easy. Students only draw and count what they are looking for. However, in reality not a few students who have difficulty in understanding the concepts of geometry taught, among others, it appears that students find it difficult to recognize and understand geometry figure and elements of geometry [21]. This is supported by [16] who argues that students' difficulties in learning geometry are closely related to students' mathematical abilities. In addition, the available textbooks generally also encourage teachers to teach mathematics mechanically and algorithmically [6, 7, 9]. Teachers often depend on Mathematics books in the process of designing learning to be carried out in class [2, 26]. Realistic Mathematics Education (RME) is an approach in mathematics education that has the potential to overcome the problems mentioned above. In RME, students will learn mathematics concepts based on their daily experiences. In addition, students will also have many opportunities to discover their own mathematical concepts under the guidance of the teacher, so that their understanding of the mathematical concepts learned will be more enjoyable and meaningful $[13,25$, 28].

The RME approach is potential to be used due to the unsuccessful implementation of Modern Mathematics or New Math in Indonesia which has been going on for more than four decades. Indicators of failure can be seen from several aspects, such as: student mathematics learning outcomes are generally low, mathematics learning processes are generally carried out mechanically and conventionally, and many teachers do not master the mathematical concepts taught [9, 10, 17, 23, 24]. As a 
result, the knowledge obtained by students is less meaningful and quickly forgotten [7, 8].

Through this research a learning trajectory was developed for the lowest common multiple concept in fourth grade elementary school. This learning flow is designed in such a way that allows students to find formal concepts through the provision of contextual questions and mathematical horizontal and vertical processes. During the process, students will be actively involved physically and mentally in learning mathematics by doing activities in mathematics. The formulation of problems answered through this research is: What are the characteristics of RME-based learning flow for the topic of flat and valid and practical to improve the reasoning ability of fourth grade elementary school students?

The product in this research is Local Instructional Theory (LIT) or a learning flow based on the RME approach. The initial form of the product is in Hypothetical Learning Trajectory (HLT) form. The term HLT was first coined by [22], which states that it is a learning flow consisting of learning objectives, learning activities, and the learning process hypotheses to predict how students' minds and understanding develop in the context of learning activities ". Based on this opinion it appears that HLT consists of three components namely, learning objectives for meaningful learning, a set of tasks to achieve these goals, and hypotheses about how students learn and how students think.

HLT contains a learning flow plan that consists of, (1) how to teach mathematics in some topics, (2) activities in solving contextual questions, (3) students' answers prediction in solving contextual questions, and (4) anticipating theories about the predication of students' answers $[1,14]$. To be more operational, a learning plan and a student worksheet were designed.

\section{Methods}

The development model utilizes development research design research method is to combine two design research models namely Plomp and Gravemeijer \& Cobb design models. The development of learning models in the form of student learning paths and books are designed by the Plomp model [20], for the development of content from a model support system designed with the Gravemeijer and Cobb models [15], to produce valid, practical, and effective products.

The prototype/ learning flow phase is combined with Gravemeijer \& Cobb [15] which consists of three phases, namely preparing for the experiment, conducting the experiment, and retrospective analysis. Based on these phases, a reflection relationship between theory and experiment can be seen in Figure 1.

Describing the activities carried out in each phase of the design research that has been carried out:

1. Preparing for the Experiment the preparatory phase for the preparation phase for the experiment is to formulate the HLT that will be used during the research process.

2. Conducting the Experiment (Stage of Implementation) the second stage is to test and carry out the conjecture that has been made in the preparation stage and design developers carried out.

3. The Retrospective Analysis The third stage is the retrospective analysis. Activity at this stage is to evaluate the HLT that has been designed to run as expected.

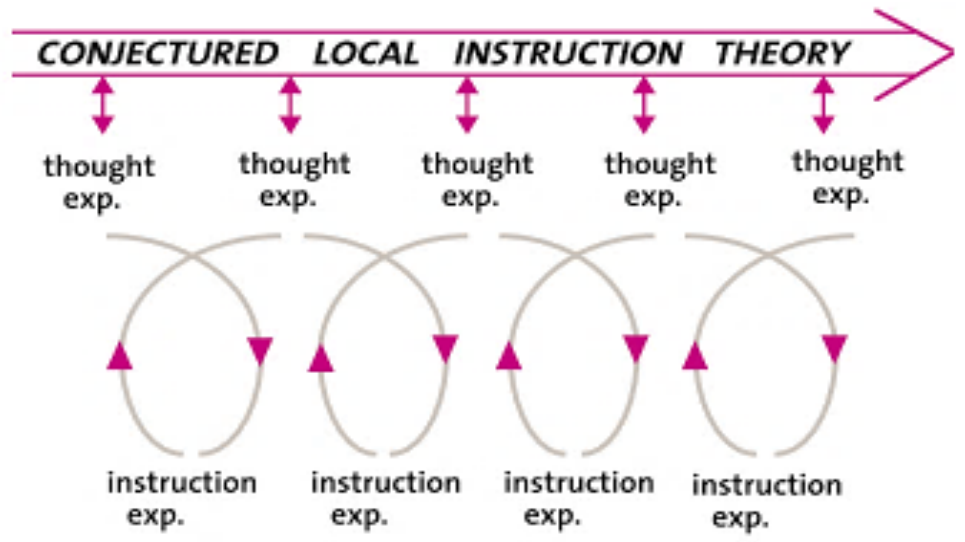

Gambar 9. The Thought \& Classroom Experiment Cyclical Process[15] 


\section{Result and Discussion}

The initial phase of the study analyzed the needs, curriculum, concepts, characteristics of students and literature review. Based on the preliminary analysis, HLT was designed to two-dimentional figure.

\subsection{Prototype Design}

\subsubsection{Designing Hypothetical Learning Trajectory}

At this stage the Hypothetical Learning Trajectory (HLT) was designed, and this HLT's design adopted the HLT by Simon [1, 22] consisting of three parts namely; learning objectives, activities and predictions of student answers, teacher anticipation, how students answer and students' thinking processes. The purpose of learning here is intended targets or achievements that have to be understood by students after they have studied a mathematics concept. Learning objectives are set at the beginning and then followed by a series of activities and students' predictions answers and answers anticipation by the teacher by giving inducement questions to achieve the learning objectives that have been set. The inducement question is given to stimulate students' predictions answers so that the learning objectives set can be achieved. Student activities and students' predictions answers are designed starting from simple and then continued with more complex problems. This activity is expected to be able to develop the ability of horizontal mathematical towards vertical mathematics. The following rational HLT is designed:

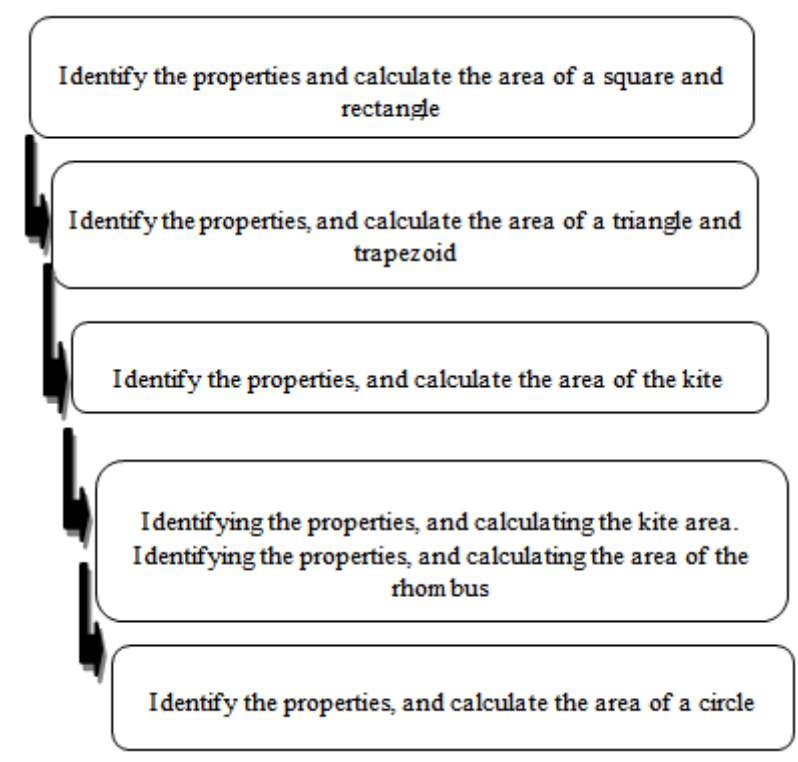

Figure 1. Two Dimentional Figures Learning Flowchart

Five HLTs were designed in this statistic topic research, the first stage is identifying the properties and calculating the area of square and square through observing ceramics different shapes and sizes activity. This activity aims to enable students to identify the shape of ceramics and to mention their properties and to be able to count lots of ceramics so they can understand the area of a flat shape. Students will understand that the area of a flat figure is a square that covers two dimentional figures.

Secondly identify the properties, and calculate the area of a triangle and trapezoid by observing the shape of the Malay house. Activities were asked to identify the shape of the platform and roof of the traditional house. The concept found through this activity is students can identify the properties of triangles and trapezoid, and can calculate the area of a two dimentional figures.

The third identifies the properties, and calculates the kite area of the kite song. The purpose of the activity is to identify the characteristics and calculate the area of the kite. The problem that is predicted to stimulate students to calculate the area of a kite is a problem related to how students make a kite, and calculate how much paper is needed to make a kite.

The fourth identifies the properties, and calculate the area of rhombus by making a large, diamond shaped rhombus envelope. The purpose of the activity is to identify the properties and calculate the area of the rhombus. The contextual problem that arises leads students to calculate the area of the diamond. Through the contextual problem of making money envelopes made from flannel cloth.

The fifth step is to identify the properties, and count the circle by observing the shape of the canai bread and making the bottom of the glass. Activities provide opportunities for students to discover the nature and extent of a circle. The contextual problem given is that students are asked to make a circular glass base and count how much material is spent on making a glass base if the diameter of the glass base is $7 \mathrm{~cm}$.

\subsubsection{Designing Teacher's Books and Students' Books}

The teacher and student book developed utilized the RME approach was not bound by any curriculum. This teacher's book could be used by teachers in any curriculum, because the presentation of the material was not arranged based on certain indicators, but based on the existence of linkages between topics so that students can learn the topics evenly as a complete.

\subsection{Formative Evaluation}

Formative evaluations are agreed available to assess the quality of the product design developed. To assess the quality of HLT design results, teacher books, and student books use formative evaluation developed by [27] which consists of expert validation, interviews all of the students, small groups or small groups (small groups) or micro evaluation), then field tests.

At this stage, blunders happen in literal, impure sentences and punctuation mistakes. Aimed at the sample 
in HLT, an error occurs repetition on the words "student can", inscribed on the HLT word "student can get". Mistake in punctuation for sample, after punctuation is not given a space of one space. The Teacher's Book the paint of the form used reasons the text to be imprecise, then consumes likewise been modified. When self-evaluation of the education scheme and the Geometric Realistic Models that have been premeditated, additional developments are complete.

\subsubsection{Result of validation learning design}

After self-evaluation, the learning design was validated by 5 validators, 3 lecturers in mathematics, 1 lecturer in educational technology and 1 lecturer in Indonesian. In the HLT aspects observed are the content and language aspects.

Table 1. Result of HLT validation

\begin{tabular}{|c|c|c|}
\hline Aspect & Validity (\%) & Criteria \\
\hline Content & 82 & Very valid \\
\hline Language & 87.5 & Very valid \\
\hline Lesson plan validity & 84.75 & Very valid \\
\hline
\end{tabular}

Through the validation procedure there are some corrections recommended by the validator. The general validity assessment of HLT is $84.75 \%$ of a very valid category. Therefore, it dismisses to be determined that the HLT component aspects are also two dimentional figures on the Realistic Geometry model. Creation applications (books of teacher and student), remained too validated. The result of the teacher's book validation is stated in Table 2 .

Table 2. Result of teachers' book validation

\begin{tabular}{|c|c|c|}
\hline Aspect & Validity (\%) & Criteria \\
\hline Content & 79.15 & Valid \\
\hline Language & 75 & Valid \\
\hline Didactic & 93.73 & Very valid \\
\hline Lesson plan validity & 75 & Very valid \\
\hline Total & 80.72 & Very valid \\
\hline
\end{tabular}

In the teacher's book the observed aspects are the didactic or presentation aspects, material and content aspects, linguistic aspects, and graphic or display aspects. The overall validity value of teacher's books is $80.72 \%$ with a very valid category. Thus it can be concluded that the Geometry Realistic Teacher's Book model that was designed was valid.

Table 3. Result of students' book validation

\begin{tabular}{|c|c|c|}
\hline Aspect & Validity (\%) & Criteria \\
\hline Content & 75 & Valid \\
\hline Language & 85.4 & Very valid \\
\hline Didactic & 85.4 & Very valid \\
\hline Lesson plan validity & 87.5 & Valid \\
\hline Total & 83.32 & Very valid \\
\hline
\end{tabular}

In the student book the observed aspects are the didactic or presentation aspects, material and content aspects, linguistic aspects, and graphic or display aspects. During the validation process there are several revisions suggested by the validators. The value of the validity of student books as a whole is $83.32 \%$ with a very valid category. Thus it can be concluded that the student book of the Geometric Realistic model that was designed is valid.

\subsubsection{Result of Implementation Learning Design}

When altogether the produces advanced remain valid, then individual evaluation is carried out through 3 learners in fourth grade elementary school Pekanbaru by small, intermediate and high capacities. The major convention is a different evaluation with 2 hours of easy education; formerly a comfortable interview is directed. Furthermore, books are assumed to learners to be concluded by these students at home-grown. Subsequently the then 3 days relaxed interviews remained directed to request their response to the learning flow contained in the book. Established on the outcomes of interviews with learners in the individual evaluation stage, in general high, intermediate and low ability students can comprehend the contextual problems presented in contextual problems that serve as starting points in finding each idea.

Large group trials (field tests) are also called conducting second cycle conducting experiments. This learning begins with a class discussion, students sit in four groups, occasionally there are also students only discussing in pairs. This class discussion not only aims to build and develop student interactivity in accordance with the characteristics of the four realistic, as well as stimulating students' basic knowledge about the concept of two dimentional figures.

Based on the results of the questionnaire given to teachers and students. The following results are obtained

Table 4. Result of the practicality of teacher

\begin{tabular}{|c|c|c|}
\hline Aspect & Practically (\%) & Criteria \\
\hline Attractiveness & 84.4 & Practical \\
\hline Usage process & 88.7 & Very Practical \\
\hline Practicality & 87.5 & Very Practical \\
\hline time efficiency & 89.6 & Very Practical \\
\hline Total & 87.5 & Very Practical \\
\hline
\end{tabular}

The practicality value of flat figure learning design obtained from the teacher questionnaire was $87.5 \%$ with a very practical category based on practicality criteria. Thus it can be concluded that the teacher considers the design of the learning of flat geometrical realistic models practically used in fourth class Pekanbaru.

Table 5. Result of the practicality of student

\begin{tabular}{|c|c|c|}
\hline Aspect & Practically (\%) & Criteria \\
\hline Attractiveness & 82.8 & Practical \\
\hline Usage process & 84.8 & Practical \\
\hline Practicality & 85 & Very Practical \\
\hline Time efficiency & 82.5 & Practical \\
\hline Total & 83.8 & Practical \\
\hline
\end{tabular}


The reasonableness significance of two dimentional figures learning design found since learner questionnaires remained $83.8 \%$ through a real classification established on practicality criteria. After the outcomes of the form investigation occupied out by learners, the scheme of a flat figure education is relaxing to use, curious, can be sound understood, can inspire learners to study mathematics and invention perceptions fine. Therefore it can be decided that learners deliberate the project of the geometrical learning of the Geometric Realistic model practically used in fourth class elementary Pekanbaru.

\subsubsection{Result of effective learning design}

The effectiveness of the RME-based flat learning flowchart can be seen from the scores obtained by students through the Mathematical Reasoning test. The ability of students to solve problems in different ways. The learning process starts from vertical mathematics to horizontal mathematics. The ability of students to build the concept of a flat figure is different for each student. The learning strategies you use are also different. Variations in answers and ways of answering given students show that students' reasoning abilities are better compared to before.

Table 6. Result of students reasoning ability

\begin{tabular}{|c|c|c|}
\hline Reasoning Indicators & $\begin{array}{c}\text { Practically } \\
\text { (\%) }\end{array}$ & Criteria \\
\hline $\begin{array}{c}\text { Observing patterns or regularities } \\
\text { to make generalizations }\end{array}$ & 71.67 & Success \\
\hline $\begin{array}{c}\text { Giving an explanation using facts } \\
\text { and their properties }\end{array}$ & 74.17 & Success \\
\hline $\begin{array}{c}\text { Providing an explanation using } \\
\text { the concept and its properties }\end{array}$ & 78.33 & $\begin{array}{c}\text { Very } \\
\text { Success }\end{array}$ \\
\hline $\begin{array}{c}\text { Constructing or assess } \\
\text { mathematical arguments }\end{array}$ & 75 & Success \\
\hline $\begin{array}{c}\text { Describing the logical conditions } \\
\text { about the number of ideas and } \\
\text { their interrelations }\end{array}$ & 78.33 & $\begin{array}{c}\text { Very } \\
\text { Success }\end{array}$ \\
\hline
\end{tabular}

The effectiveness of the RME-based flat learning flowchart can be seen from the students' mathematical reasoning ability of all indicators that are critically successful and very successful with an average reasoning ability of $75.5 \%$ with very successful criteria.

\section{Conclusions}

HLT / learning flow on realistic-based designed to two-dimentional figure developed in this study fulfills valid criteria, with characteristics: learning paths reflect the state of the art knowledge, and according to realistic principles and characteristics, also meet practical criteria because they can work according to hypothesized, and effective in increasing students' reasoning abilities.

\section{REFERENCES}

[1] Alim, J.A., Fauzan, A., Arwana, I.M., \& Musdi, E. (2020). Model of Geometry Realistic Learning Development with Interactive Multimedia Assistance in Elementary School. Journal of Physics: Conference Series 1471012053.

[2] Beaton, A. E., Mullis, I. V. Martin, M. O., Gonzalez, E. J., Kelly, D. L., \& Smith, T. A. (1996). Mathematics achievement in the middle school years: IEA's third international mathematics and science study (TIMSS). Boston, MA: Center for the Study of Testing, Evaluation, and Educational Policy, Boston College

[3] Biber, C., Tuna, A. \& Korkmaz, S. (2013). The mistakes and the misconceptions of the eighth grade students on the subject of angles. European Journal of science and mathematics education, 1 (2), 50-59.

[4] Clements, D. H. \& Battista, M. T. (1992). Geometry and spatial reasoning. In D. A. Grouws (Ed), Handbook on mathematics teaching and learning. (pp. 420-464). New York: Macmillan.

[5] Elisha, HZ dan Kevin, SK. 2015. Teacher's Knowledge of Students about Geometry. International Journal of Learning, Teaching and Educational Research Vol. 13, No. 3, pp. 100-114, October 2015.

[6] Fauzan, A. (2002). Applying Realistic Mathematics Education (RME) in Teaching Geometry in Indonesian Primary Schools. Enschede, The Netherlands: PrintPartners Ipskamp.

[7] Fauzan, A. (2015). Pengembangan Alur Belajar dengan Pendekatan Realistic Mathematiccs Education (laporan penelitian). LPM UNP Padang.

[8] Fauzan, A., Plomp, T., \& Gravemeijer, K. (2013). The development of an RME-based geometry course for Indonesian primary schools. Educational Design Research Part B: Illustrative Cases, 159-178.

[9] Fauzan, A., Plomp, T., Gravemeijer, K. (2013). The Development of RME-based Geometry Course for Indonesian Primary Schools. In An Introduction to Educational Design Research. T. Plomp, T., N. Nieveen N. (Eds). The Netherlands: SLO.

[10] Fauzan, A., Slettenhaar, D. \& Plomp, T. (2002). Traditional Mathematics Education vs. Realistic Mathematics Education: Hoping for Changes. Proceeding of the 3rd Mathematics Education and Society (MES) conference, Helsinghor, Denmark.

[11] Fauzan, A., Slettenhaar, D. \& Plomp, T. (2002a). Teaching Mathematics in Indonesian Primary Schools Using Realistic Mathematics Education (RME)-Approach. Proceeding of the Second International Conference on the Teaching of Mathematics (ICTM2). John Wiley \& Sons

[12] Gravemeijer, K. (1997). Instructional design for reform in mathematics education. In M. Beishuizen, K.P.E. Gravemeijer, \& E.C.D.M. van Lieshout (Eds.), The Role of Contexts and Models in the Development of Mathematical Strategies and Procedures. Freudenthal Institute, Utrecht.

[13] Gravemeijer, K. 1994. Developing Realistic Mathematics Education. Utrecht: Freudenthal Institute. 
[14] Gravemeijer, Koeno and Cobb, Paul. (2013). Design research from the Learning Design Perspective. Dalam Jan Ven Den Akker, et. al. An Introduction to Educational Design Research. London: Routledge.

[15] Gravemeijer, Koeno and Cobb, Paul. 2006. Design research from the Learning Design Perspective. Dalam Jan Ven Den Akker, et. al. Educational Design Research. London: Routledge

[16] Idris, Noraini. (2011). The Impact of Using Geometers' Sketchpad on Malaysia Students' Achievement and van Hiele Geometric Thinking. Journal for Mathematics Education Vol.2, No.2 pp 94-107. University of Malaya, Malaya

[17] Marsigit. (2000). Empirical Evidence of Indonesian Styles of Primary Teaching. Paper presented at the ICME conference, Hiroshima Japan, July 23-27

[18] National Council of Teacher of Mathematics [NCTM]. 2000. Executive Summary Principles and Standards for School Mathematics.

[19] Ozerem, A. (2012). Misconceptions in geometry and suggested solutions for seventh grade students. International Journal of New Trends in Arts, Sports \& Science Education, 1(4).

[20] Plomp, T dan N. Nieveen. (2013). Educational Design Research. Enshede: Netherlands Institute for Curriculum Development (SLO)
[21] Saragih, M.S. (2008). Rancangan dan Implementasi Program Perangkat Ajar serta Rancangan Materi Perangkat Ajar Geometri SMU Kelas I Berbantuan Komputer. Forum Penelitian Pendidikan, Thn 8.

[22] Simon, Martin A. 1995. Reconstructing Mathematics Pedagogy from a Conswtructive Perspective. Journal of Research in Mathematics Education. Vol. 26. No.2. 135-137. Diakses pada tanggal 20 April 2016

[23] Soedjadi. (2000). Kiat-kiat Pendidikan Matematika di Indonesia. Jakarta: Dirjen Dikti Depdikbud.

[24] Somerset, A. (1997). Strengthening Quality in Indonesia's Junior Secondary School: An Overview of Issues and Initiatives. Jakarta: MOEC.

[25] Streefland, L. (1991). Realistic Mathematics Education in Primary Schools. Utrecht, The Netherlands: Freudenthal Institute.

[26] Sun, Y., Kulm, G., \& Capraro, M. M. (2009). Middle grade teachers ${ }^{\text {ee }}$ use of textbooks and their classroom instruction. Journal of Mathematics Education, 2(2), 20-37.

[27] Tessmer, Martin. 1996. Planning and Conducting Formatif Evaluation. London: Kogan Page

[28] Treffers, A. (1987). Three dimensions. A model of Goal and Theory Description in Mathematics Education, Dordrecht, The Netherlands: Reidel 